\title{
Evaluation of the biodegradation of polyethylene, polystyrene and polypropylene, through controlled tests in solid suspension with the fungus Aspergillus flavus
}

\author{
Evaluación de la biodegradación del polietileno, poliestireno y polipropileno, \\ mediante ensayos controlados en suspensión sólida con el hongo Aspergillus flavus
}

\author{
S. Santacoloma-Londoño iD, M. E. Buitrago-González iD, V. Lamus-Molina iD , S. Asprilla- \\ Asprilla , J. E. Ruíz-Terán iD , L. C. Villegas-Méndez iD
}

\begin{abstract}
Plastics have a high resistance to degradation so they last several years in the environment, generating impacts that make it necessary to find mechanisms that contribute to their decomposition. This study evaluated the biodegradation of plastics such as polyethylene, polystyrene and polypropylene using the Aspergillus flavus fungus, obtained and incubated in the laboratory. The fungus planted in two types of agar (YGC and SDA) was put in contact with the three types of plastic. It was observed that by using two types of agar such as Yeast extract glucose chloramphenicol Agar (YGC) and Sabouraud Dextrose Agar (SDA) for the cultivation of the Aspergillus flavus fungus, there were favorable conditions for the biodegradation of the plastic, leading to better results with YGC agar, since it was possible to obtain a maximum reduction in the polyethylene mass of $23.6 \%$ with respect to the initial mass. It was demonstrated that A. flavus degrades polyethylene in greater percentages to other fungi, such as $A$. niger, and other plastics such as polystyrene and polypropylene. The multifactor ANOVA, used as a dependent variable the decrease in the percentage of mass of the plastic and as factors the type of agar and the type of plastic, showed that the type of agar used, had greater incidence, and was more selective for the Aspergillus flavus agar YGC The result of the multifactor ANOVA accepts the alternative hypothesis: there are differences between YGC and SDA agars in the plastics used in the tests.
\end{abstract}

Index Terms- Aspergillus flavus, Biodegradation, fungus, polyethylene, polypropylene, polystyrene, SDA, YGC

This manuscript was sent on January 25, 2019 and accepted on September 27, 2019. This work was supported by the U. Central del Valle del CaucaUCEVA for its realization.

S. Santacoloma-Londoño, research group in Natural Resources and Environmental Management-Tolues, Environmental Engineering, U Central del Valle del Cauca-UCEVA Colombia. (email ssantacoloma@uceva.edu.co).

M.E. Buitrago-González, a member of the Natural Resources and Environmental Management-Tolues Research Group, Environmental Engineering, U. Central del Valle del Cauca-UCEVA Colombia. (mail mbuitrago@uceva.edu.co).

V. Lamus-Molina, member of the Proagro research group, Environmental Agricultural Engineering, U. Central del Valle del Cauca-UCEVA Colombia. (email vlamus@uceva.edu.co).
Resumen- Los plásticos poseen una alta resistencia a la degradación por lo que perduran varios años en el ambiente, generando impactos que hacen necesario la búsqueda de mecanismos que contribuyan a su descomposición. Este estudio evaluó la biodegradación de plásticos como el polietileno, poliestireno y polipropileno mediante el hongo Aspergillus flavus, obtenido e incubado en el laboratorio. El hongo sembrado en dos tipos de agar (YGC y SDA) fue puesto en contacto con los tres tipos de plástico. Se observa que mediante el uso de dos tipos de agar como el Yeast extract glucose chloramphenicol Agar (YGC) y el Agar Sabouraud Dextrose (SDA) para el cultivo del hongo Aspergillus flavus se tuvieron condiciones favorables para la biodegradación del plástico, siendo mejores los resultados hallados con el agar YGC, con un valor máximo de disminución de la masa del polietileno del $23,6 \%$ con respecto a la masa inicial. Se demostró que el $A$. flavus degrada el polietileno en porcentajes mayores a otros hongos, como $A$. niger, y a otros plásticos como poliestireno y polipropileno. El ANOVA multifactorial, usó como variable dependiente la disminución del porcentaje de masa del plástico y como factores el tipo de agar y el tipo de plástico, arrojó que tuvo mayor incidencia el tipo de agar utilizado, y fue más selectivo para el Aspergillus flavus el agar YGC. El resultado del ANOVA multifactorial acepta la hipótesis alternativa: sí existen diferencias entre los agares YGC y SDA en los plásticos utilizados en los ensayos.

Palabras claves- Aspergillus flavus, biodegradación, hongo, polietileno, polipropileno, poliestireno, SDA, YGC.

S. Asprilla-Asprilla, Graduated Environmental Engineering program, former seedbed of research in Natural Resources and Environmental ManagementTolúes, U. Central del Valle del Cauca-UCEVA Colombia. (mail stefanya101@ @otmail.com).

J.E. Ruíz-Terán, a student of the seedbed of research in Natural Resources and Environmental Management-Tolues, Environmental Engineering, U. Central del Valle del Cauca-UCEVA, Colombia. (Email juanesmool@hotmail.com).

L.C. Villegas-Méndez, member of the research group on Natural Resources and Environmental Management-Tolues, Environmental Engineering, U. Central del Valle del Cauca-UCEVA, Colombia. (mail lvillegas@uceva.edu.co). 


\section{I.INTRODUCTION}

$\mathrm{P}$ LASTIC is the most useful synthetic substance, composed of elements extracted from fossil fuel resources. This material has made most of the industrial and technological revolutions of the nineteenth and twentieth centuries possible [1]. In recent years, the consumption of plastic has been increasing exponentially as thousands of bags, with an average time of use that can be measured in seconds, are thrown away, so the amount of waste also increases rapidly.

Plastic products have very versatile qualities, among those which stand out are their durability and resistance to degradation, so they have an extended use in the manufacturing of a wide variety of products, which are essential for the current lifestyle [2]. Plastics do not decompose easily in the environment because they are resistant to microbial attack due to their large molecular mass, high number of aromatic rings, or halogen substitutions [1].

Due to the characteristics presented by plastics, it is necessary to develop strategies that facilitate their reduction, since there is no balance between production that is very high compared to its natural elimination, which oscillates for plastic bottles among the 100 and 450 years while the stock exchanges take around 150 years to carry out this process [3].

Nowadays, due to the environmental problems caused by the generation of plastic waste, management methods aimed to reduce its adverse effect on the environment are being implemented, because the commonly used methods which involve the stacking and burning of plastic transfer the problem but do not solve it efficiently.

One of the methods that has been studied is the bioremediation, which is the name given to processes that use plants, microorganisms and fungi among others, for the biodegradation of contaminants, thus becoming a method that is compatible with nature and the environment. Biodegradation is the ability of one or more strains of microorganisms to use a synthetic polymer as the sole source of carbon and energy; Some types of plastics such as polyhydroxyalkanoates (Polyhydroxybutyrate PHB) and polylactic acid (PLA) are highly biodegradable, while synthetic polymers such as polyethylene (PE) polycaprolactone (PCL) and polystyrene (PS) have low biodegradability [4].

In the bioremediation process, certain factors must be taken into account, since there are situations that tend to present slow processes in terms of the reduction of a specific contaminant agent; however, they tend to have favorable results in terms of degradation. In the process of biodegradation of plastics, there are two different situations: a direct action, in which the transformation of plastics provides food for microbial growth, and an indirect action in which the metabolic products of microorganisms affect the plastic structure. [5].

The main groups of microorganisms and the degradation pathways of the polymer often depend on environmental conditions; At least two categories of enzymes are involved in biological degradation: extracellular enzymes and intracellular enzymes. The enzymes secreted by microorganisms for the biodegradation of plastics are mainly lipase, proteinase $\mathrm{K}$, dehydrogenases. [6]

The specific case of this study uses bioremediation using a fungus of the family Aspergillaceae, which is composed of approximately 180 species, of which five or six are opportunistic pathogens. [7]

Within this family of fungi, is the genus Aspergillus, in particular the species Aspergillus flavus, famous in agriculture for producing the white rot of the wood and causing the destruction of lignin and polysaccharides, which at the end of the process of decomposition causes a loss of resistance that leads to the fall of trees. Aspergillus flavus is a common filamentous fungus that produces aflatoxins and poses a great threat to agriculture and human health. [8]

These fungi are widely distributed, they live as saprophytes in soil, decaying vegetables, any type of organic matter, open or high-carb canned foods, old clothes, chemical reagents, hospital rooms and even soft contact lenses. [9]

Aspergillus flavus is an imperfect and opportunistic pathogenic filamentous fungus, which is capable of causing invasive and non-invasive aspergillosis in humans, animals and insects. It also causes allergic reactions in humans, infects agricultural crops as well as stored grains and also produces the most toxic and potent carcinogenic metabolites, such as aflatoxins and other mycotoxins [10].

The peculiarity of these fungi is what makes them more appropriate for the bioremediation process; The fungi of the Aspergillus genus are common, easy to find in certain rotting sites, and due to their decomposing characteristics, they become a possible plastic reducing agent.

For the cultivation of fungi, two agars were use, which are characterized as selective media for their growth: the Sabouraud Dextrose Agar (SDA) and the Yeast extract glucose chloramphenicol Agar (YGC).

The SDA is a culture medium that works as a means of enrichment for fungi due its characteristics. It contains peptones and a high concentration of glucose that favors the growth of fungi on bacteria. The YGC culture medium contains an antibiotic, chloramphenicol, to suppress the bacterial flora that may be present. Unlike other similar culture media, which contain antibiotics (e.g. oxytetracycline glucose yeast Agar), it has the advantage of being fully suitable for autoclaving and can last up to four months.

\section{II.MATERIALS AND METHODS}

In this research, the effect of the two independent variables (fungus + YGC and fungus $+\mathrm{SDA}$ ) on the dependent variable (reduction in plastic mass for each controlled test) was study.

The study sought to diminish other possible sources of change to the dependent variables to the maximum and with this to have greater certainty that the changes were due to the manipulated independent variables, which were control ensuring that they were faithful to the test established for the conditions of the contact between the fungus and the plastics.

In the experiment, the external variables were controlled, the control group was present, the selection of the plastic used in 
the experiment was completely randomized, as well as its assignment to each type of agar. Table 1 shows the organization of the experimental design for each replica (there were three replicates for each trial).

TABLE I

EXPERIMENTAL DESING FOR EACH REPLICA

\begin{tabular}{|c|c|c|c|}
\hline Test & Subjets & $\begin{array}{l}\text { Treatments } \\
\text { (independent } \\
\text { variables) }\end{array}$ & $\begin{array}{l}\text { Variable } \\
\text { dependent } \\
\text { measurements }\end{array}$ \\
\hline 1 & polypropylene & $\mathrm{X}_{1 \text { (FUNGUS + SDA) }}$ & $\mathrm{O}_{\mathrm{i} y} \mathrm{O}_{\mathrm{f}}$ \\
\hline 2 & polyethylene & $\mathrm{X}_{1 \text { (FUNGUS + SDA) }}$ & $\mathrm{O}_{\mathrm{iy}} \mathrm{O}_{\mathrm{f}}$ \\
\hline 3 & polystyrene & $\mathrm{X}_{1 \text { (FUNGUS + SDA) }}$ & $\mathrm{O}_{\mathrm{iy}} \mathrm{O}_{\mathrm{f}}$ \\
\hline 4 & polypropylene & $\mathrm{X}_{2 \text { (FUNGUS + YGC) }}$ & $\mathrm{O}_{\mathrm{iy}} \mathrm{O}_{\mathrm{f}}$ \\
\hline 5 & polyethylene & $\mathrm{X}_{2 \text { (FUNGUS + YGC) }}$ & $\mathrm{O}_{\mathrm{iy}} \mathrm{O}_{\mathrm{f}}$ \\
\hline 6 & polystyrene & $X_{2(\mathrm{FUNGUS}+\mathrm{YGC})}$ & $\mathrm{O}_{\mathrm{iy}} \mathrm{O}_{\mathrm{f}}$ \\
\hline 7 & polypropylene & $\mathrm{A}_{1(\mathrm{SDA})}$ & $\mathrm{O}_{\mathrm{iy}} \mathrm{O}_{\mathrm{f}}$ \\
\hline 8 & polyethylene & $\mathrm{A}_{1(\mathrm{SDA})}$ & $\mathrm{O}_{\mathrm{iy}} \mathrm{O}_{\mathrm{f}}$ \\
\hline 9 & polystyrene & $\mathrm{A}_{1 \text { (SDA) }}$ & $\mathrm{O}_{\mathrm{iy}} \mathrm{O}_{\mathrm{f}}$ \\
\hline 10 & polypropylene & $\mathrm{A}_{2(\mathrm{YGC})}$ & $\mathrm{O}_{\mathrm{iy}} \mathrm{O}_{\mathrm{f}}$ \\
\hline 11 & polyethylene & $\mathrm{A}_{2} \mathrm{YGC}$ & $\mathrm{O}_{\mathrm{iy}} \mathrm{O}_{\mathrm{f}}$ \\
\hline 12 & polystyrene & $\mathrm{A}_{2(\mathrm{YGC})}$ & $\mathrm{O}_{\mathrm{iy}} \mathrm{O}_{\mathrm{f}}$ \\
\hline
\end{tabular}

$\mathrm{X}$ : Treatments or experimental conditions

$\mathrm{O}=$ initial and final mass to the subjects of the group

$\mathrm{A}=$ absence of fungus, indicates that it is a control group.

The hypothesis on which we worked was the following: the use of the different agars (YGC and SDA) in the fungus, affects the percentage of reduction of the plastic mass differently in each test.

A probabilistic sampling was carried out since the pieces of plastic that were counted for the test had the same probability of being selected by a simple random sampling.

To evaluate the effects of the treatments (fungus + SDA, fungus + YGC) in plastics, it is established by means of analysis by the ANOVA variance of two factors with levels of fixed effects and completely randomized; the interest of the design focuses on knowing if these levels differ from each other.

The analysis proposes two hypotheses: Ho: null hypothesis and $\mathrm{H}_{\mathrm{A}}$ : alternative hypothesis. The Ho affirms that there were no significant effects of the independent variable on the dependent variable; that is, the YGC and SDA agars produce the same effect in all plastics.

Ho $\rightarrow \mu_{1}=\mu_{2} \rightarrow \mu_{1}-\mu_{2}=0$ where $\mu_{1}$ and $\mu_{2}$ are the means of the values of the \% reduction in the mass of the plastic at the beginning and at the end of the experiment.

The $\mathrm{H}_{\mathrm{A}}$ states that there were differences between the results at the beginning and at the end of the experiment. That is to say that the YGC and SDA agars produce different effects in all the plastics used in the tests.

$\mathrm{H}_{\mathrm{A}} \rightarrow \mu_{1} \neq \mu_{2} \rightarrow \mu_{1}-\mu_{2} \neq 0$ where $\mu_{1}$ and $\mu_{2}$ are the means of the values of the $\%$ reduction in the mass of the plastic at the beginning and at the end of the experiment.

The significance level of 0.05 or $5 \%$ level was taken as a basis to infer the intervention of non-random factors; that is to say that when $\mathrm{P}<0.05$ the alternative hypothesis is accepted and when $\mathrm{P}>0.05$ the null hypothesis is accepted.

To compare the means of the populations, the two-way ANOVA analysis of variance and its interaction with the results of the dependent variables and a factor with the dependent variables were used to establish specific results using the Stat Graphics Centurium program v XVI.

The research was developed in three phases that are summarized as follows: Isolation, identification and culture of Aspergillus flavus; implementation of the biodegradation tests of polyethylene, polypropylene and polystyrene with Aspergillus flavus and finally, evaluation of the tests based on the percentage of plastic mass loss. The research was carried out in the UCEVA biology laboratory at 975 masl (meters above sea level).

\section{A. Isolation, identification and culture of Aspergillus flavus.}

Initially it was found that the fungus Aspergillus flavus can be present in corn, wheat and barley plants and in the soil of cotton and walnut plantations; It was also found that this fungus can be found in soils with a high content of organic matter, in tomato crops and in vanilla crops.

For the study, corn (Zea mays v.) was used, which detected the presence of Aspergillus flavus due to the formation of a greenish-yellow sporulation, located at the upper end of the ear similar to that shown in Fig. 1.

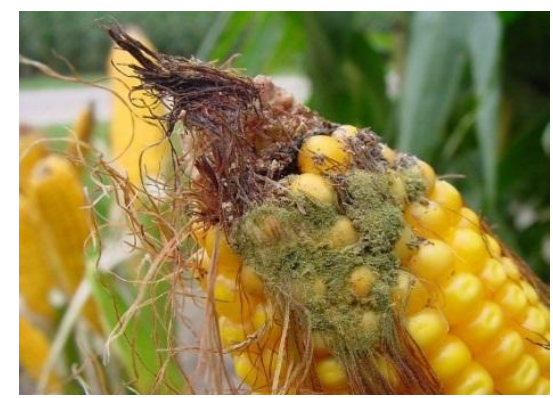

Fig. 1. Aspergillus flavus fungus in corn. [11]

Subsequently, the preparation of culture media was carried out; The agars used were Sabouraud Dextrose Agar (SDA) and Yeast Extract Glucose Chloramphenicol Agar (YGC). The amount established in the preparation is that for 25 Petri dishes per agar, $250 \mathrm{~mL}$ were prepared; for the YGC agar, $10 \mathrm{~g}$ were added and $16.3 \mathrm{~g}$ were added for the SDA agar.

To prepare the medium, sodium hypochlorite was cleaned at the worksite and the lighters were kept on. Subsequently, 220 corn kernels were selected between damaged and undamaged and subjected to disinfection with $1.0 \%$ hydrochloric acid for one minute; subsequently they were rinsed 3 times in distilled water and allowed to dry on sterile paper.

Once dried, the grains were planted in Petri dishes that already contained the SDA and YGC agars, keeping an equidistant distance between the 10 seeds contained by each of the 10 boxes used.

The Petri dishes were incubated for 7 days at $25 \pm 2$ to develop the mycobiota. After 7 days of incubation, the boxes that presented Aspergillus flavus were isolated (they showed the presence of yellowish-green color in the colonies and small heads were observed in the stereoscope).

The heads were extracted and extended with sterile glass handle, taken to new Petri dishes with SDA and YGC and 
incubated at $25 \pm 20 \mathrm{C}$ for 24 hours. After 24 hours, a growth point was extracted with a sterile needle and reseeded in Petri dishes with (SDA and YGC) to be incubated at $25 \pm 20 \mathrm{C}$ for a period of 7 days to obtain monosporic cultures.

From monosporic cultures, explants $0.5 \mathrm{~cm}$ in diameter were taken per fungus to deposit them in triplicate in Petri dishes containing SDA and YGC agar.

At the end of their incubation for 7 days at $25 \pm 20 \mathrm{C}$, the diameter of the colonies was measured, their color and appearance were observed. After 10 days of fungal growth, it is possible to determine the presence or absence of sclerotia [10].

Subsequently we proceeded with the identification of the fungus in the microscope using its macroscopic and microscopic characteristics. The macroscopic characteristics are that they are colonies of rapid growth, from 3 to 5 days; beginning with a white-yellowish, cottony hue; with time they become pulverulent and with greenish or yellowish-green tones (Fig. 2).

Regarding the microscopic characteristics, it presents a septate mycelia, macrosiphona, hyaline, branched, with long cenocitic conidiophores, near the vesicle a rough part is formed, the vesicles are spherical, covered in $360^{\circ}$ and contain from 1 to 2 series of phialides [11], [7], with a radiated and biseriada head, and conidia of approximately $3.5 \mu \mathrm{m}[12]$

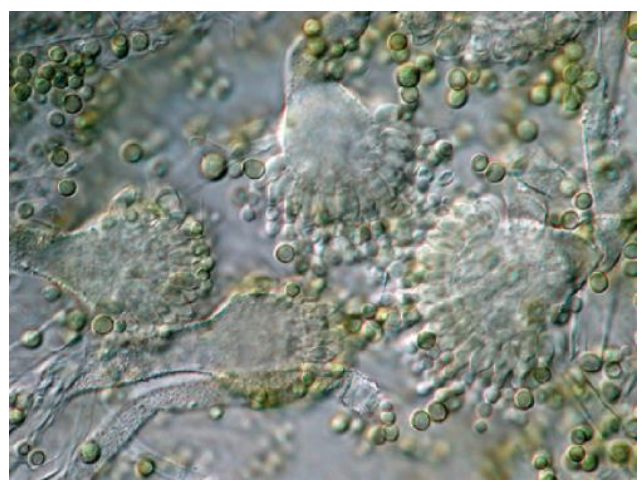

Fig. 2. Monoseria conidial heads of Aspergillus flavus in MEA. Lactophenol stain with cotton blue.100X. [13]

\section{B. Implementation of biodegradation test of polypropylene,} polyethylene and polystyrene with Aspergillus flavus.

To obtain polyethylene and polypropylene, some bottles and plastic bags were chosen, arranged in plastic collection bins in the university citadel of the (UCEVA).

The plastics used were classified as follows: Plastic type 1: packaging of milk drink (polypropylene), Plastic type 2: bag (polyethylene), Plastic type 3: disposable cup (polystyrene).

The plastic samples were washed using a brush and sterile distilled water, in some cases the sample was scraped with a knife to make it free of adhesions.

Subsequently the plastic was cut into pieces measuring 1.5 $\mathrm{cm} \times 1.5 \mathrm{~cm}$; the fractions were introduced for 60 minutes in a solution of Chloramphenicol with a final concentration of 0.5 $\mathrm{mg} / \mathrm{mL}$ and then immersed in sterile distilled water for 30 minutes. Each piece of plastic was weighed before the start of the test.
In the process of biodegradation, two agars were used in solid suspensions containing the fungus, which were put in contact with the plastic as described below. The SDA and YGC agars in Petri dishes were used as the first substrate for biodegradation, in which a previously weighed and sterilized piece of plastic was placed.

Later on each plastic sample $2 \mathrm{~cm} 2$ of mycelium grown in SDA or in YGC of the strain was added, and then three replicas of each sample were made, and all the boxes were incubated from 25 to $28^{\circ} \mathrm{C}$ for 100 days, making observations every 15 days to determine possible alterations (adapted from [14]).

As controls, Petri dishes with SDA and YGC with plastic and no fungus were used to observe if the substrate caused some type of alteration in the sample.

\section{Evaluation of the trials}

The quantitative biodegradative capacity test was carried out, which consisted in determining the mass of plastic loss in a previously established incubation period of a previously weighted plastic sheet (adapted from [15]).

Each piece of plastic was subjected to a cleaning treatment at the end of the test, adding a solution of Chloramphenicol in sterile distilled water which allowed the removal of the fungus adhering to the material.

Once the plastic was clean, the mass of each piece was determined at the end of the test and a detailed review was made under the microscope to observe the possible physical changes that could be presented in the sample.

In order to know the percentage of plastic that was degraded from the contact with the fungus, the following expression was used:

$$
\% \text { plastic mass loss in test }=\frac{\text { initial mass-final mass }}{\text { initial mass }} \times 100
$$

\section{RESULTS}

Corn ears that showed the presence of the fungus and had a characteristic green color were selected.

The selected grains of corn presented a certain degree of alteration and clean grains were also included; In addition to this, part of the protective cover of the ear was taken to have more possibilities of obtaining the fungus.

Sowing of clean and infected beans was done, which underwent the proper disinfection process; In addition, grains, which did undergo a disinfection process, were planted in separate boxes, in order to reduce the chances of the fungus being eliminated under these conditions.

After Petri dishes were selected with fungi that had shape and color approximate to the standards that were taken as reference, the respective observation was made under the microscope and after several attempts, the desired fungus species was reached.

\section{A. Fungus A. flavus in contact with different types of plastic}

Three types of plastic were taken: milk drink packaging (polypropylene), plastic bag (polyethylene) and disposable cup (polystyrene), which received an adequate cleaning and cutting for later contact with the fungus in the Petri dishes, and were taken to incubation for 100 days. 
Observations were made of the Petri dishes in which some, bacteria was found when the SDA agar was used, while the use of the YGC agar was more specific to the presence of the $A$. flavus fungus. The images that show some evidence of contamination of the SDA compared to YGC are presented below.

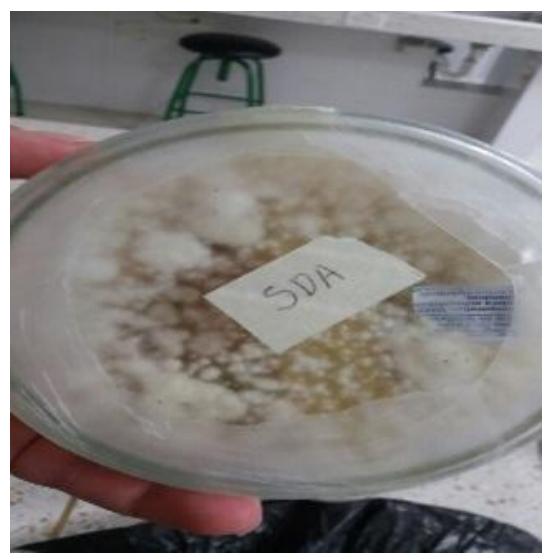

Fig. 3. Assay with agar SDA

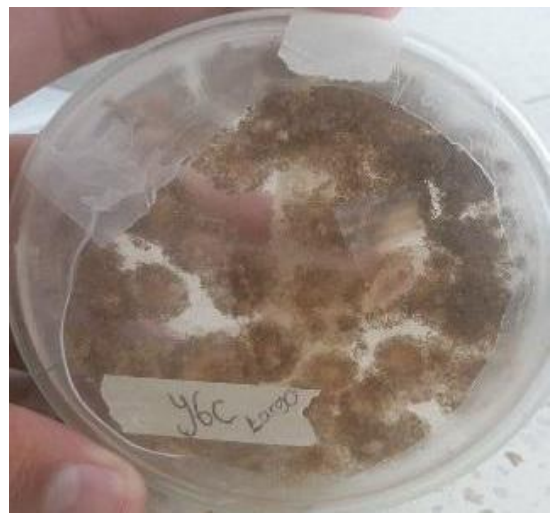

Fig. 4 Assay with agar YGC

After a period of 100 days, the plastic was extracted from the Petri boxes, which was in contact with the fungus for approximately 100 days, washed with abundant distilled water and left for about 20 minutes to rest. $1.0 \%$ hydrochloric acid; then the plastic was taken to the scales to know its final weight and thus the calculation of the percentage of its biodegradation was possible; Additionally the plastic was observed under the microscope to identify possible changes of the plastic samples after the tests.

B. Determination of the mass before and after the tests

TABLA II

AVERAGE OF PLASTIC MASS MEASUREMENTS

\begin{tabular}{ccccc}
\hline Plastic & Agar & $\begin{array}{c}\text { Initial } \\
\text { mass, }\end{array}$ & $\begin{array}{c}\text { Final mass, } \\
\mathrm{g}\end{array}$ & $\begin{array}{c}\% \text { mass } \\
\text { decrease }\end{array}$ \\
\hline 1 & SDA & 0,0247 & 0,0247 & 0,00 \\
2 & SDA & 0,0095 & 0,0093 & 2,11 \\
3 & SDA & 0,0218 & 0,0216 & 0,92 \\
1 & YGC & 0,0299 & 0,0258 & 13,7 \\
2 & YGC & 0,0076 & 0,0056 & 23,6 \\
3 & YGC & 0,0277 & 0,0277 & 0,00 \\
1 & Control SDA & 0,0249 & 0,0246 & 1,20 \\
2 & Control SDA & 0,0098 & 0,0098 & 0,00 \\
3 & Control SDA & 0,0219 & 0,0219 & 0,00
\end{tabular}

\begin{tabular}{lllll}
1 & Control YGC & 0,0287 & 0,0286 & 0,35 \\
2 & Control YGC & 0,0088 & 0,0086 & 2,27 \\
3 & Control YGC & 0,0280 & 0,0280 & 0,00 \\
\hline \hline
\end{tabular}

Plastic 1: polypropylene Plastic 2: polyethylene

Plastic 3: polystyrene

\section{Multivariate ANOVA - \% Plastic mass reduction}

For this analysis the dependent variable was the percentage in mass reduction of the plastic and the factors were the type of Agar and the type of plastic.

The ANOVA multifactorial analyzes the variance of the two factors (type of Agar and type of plastic), to evaluate its incidence in the dependent variable (\% reduction in the plastic mass) and determines what factors have an effect statistically significant over the \% of reduction in the mass of the plastic and also evaluates the significance of the interactions between factors.

On the other hand, the trials-F in the ANOVA table allow identification of significant factors; the multiple range tests identify the means that are significantly different from others and mean and interaction graphs help interpret significant effects. (Table 3)

TABLA III

\begin{tabular}{lcccc}
\multicolumn{6}{c}{ VARIANCE ANALYSIS PARA \% PLASTIC MASS REDUCTION } \\
\hline \hline Source & Gl & $\begin{array}{c}\text { Middle } \\
\text { Square }\end{array}$ & $\begin{array}{c}\text { Reason } \\
\mathrm{F}\end{array}$ & Value P \\
\hline $\begin{array}{c}\text { MAIN EFFECTS } \\
\text { A: Type of }\end{array}$ & 1 & 672,93 & 20,0 & 0,0005 \\
$\quad \begin{array}{l}\text { Agar } \\
\text { B: Type of } \\
\text { plastic }\end{array}$ & 2 & 279,03 & 8,29 & 0,0042 \\
\hline
\end{tabular}

The ANOVA table breaks down the variability of the $\%$ reduction in plastic mass into contributions due to both factors. The contribution of each factor is measured by eliminating the effects of the other factors; the P-values prove the statistical significance of each one of the factors; in this specific case, because the $\mathrm{P}$ values are less than 0.05 the alternative hypothesis is accepted; that is to say that the factors (Type of Agar and Type of Plastic) have a statistically significant effect on the \% reduction in the mass of the plastic with a $95.0 \%$ level of confidence.

Fig. 5, shows that according to the type of plastic, the one that obtained the best results in terms of the percentage of plastic mass reduction, was polyethylene and according to agar the YGC obtained better results.

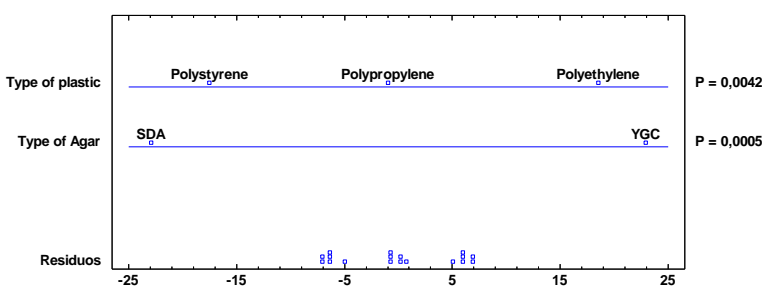

Fig. 5. ANOVA graph for $\%$ reduction in plastic mass according to the two factors. 
Fig 6 and 7 they are evident that in the tests where the SDA agar was used there was not much dispersion regarding the result of the percentage in reduction of the mass; in other words, the agar behaved in a similar way without taking into account the type of plastic that was used, while for YGC agar different values of the percentage of removal were obtained, which were grouped according to the type of plastic, but which were different among the types of plastic.

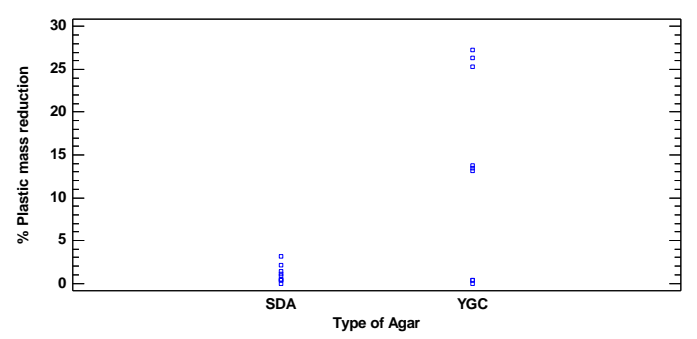

Fig. 6. Dispersion of \% reduction in plastic mass according to the type of agar.

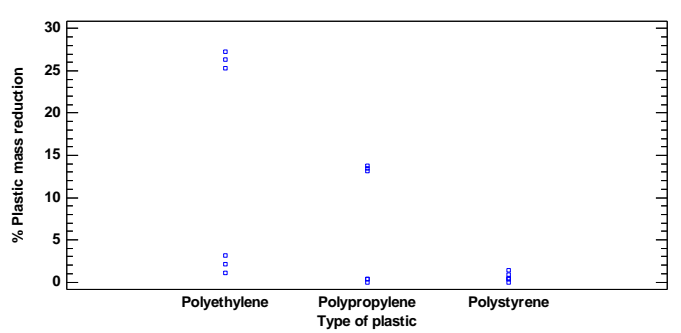

Fig. 7. Dispersion of $\%$ reduction in plastic mass according to the type of plastic.

As a complement to the analysis, the method used to discriminate between the means is Fisher's minimum significant difference (LSD) procedure, which showed that, as already mentioned, YGC agar gave better results (Fig. 8).

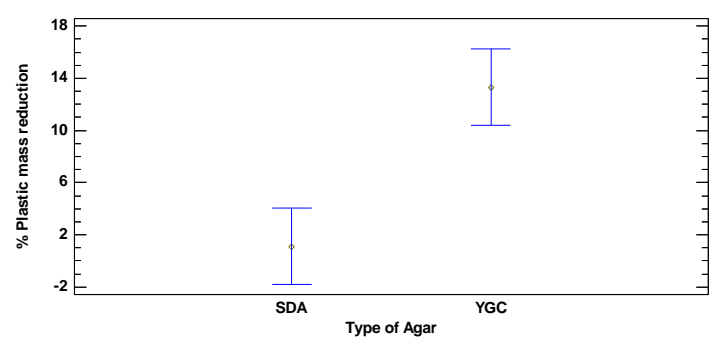

Fig. 8. Fisher's minimum significant difference for $\%$ mass reduction according to agar.

And for the case of plastic types, the bag (polyethylene) obtained the best result (Fig 9).

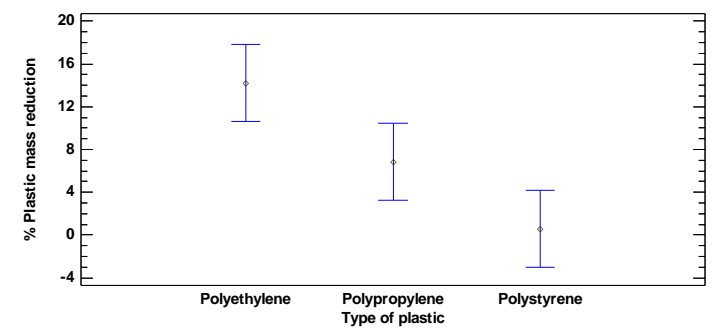

Fig. 9. Fisher's minimum significant difference for $\%$ mass reduction according to the type of plastic

On the other hand, when the study of each factor was made separately by simple ANOVA, the results obtained with the multifactorial ANOVA were confirmed.

Fig 10 and 11 show that the best result of \% reduction in plastic was obtained in type 2 plastic: the polyethylene bag. And as it pertains to the agars, the best value in \% reduction of the plastic was obtained when using YGC.

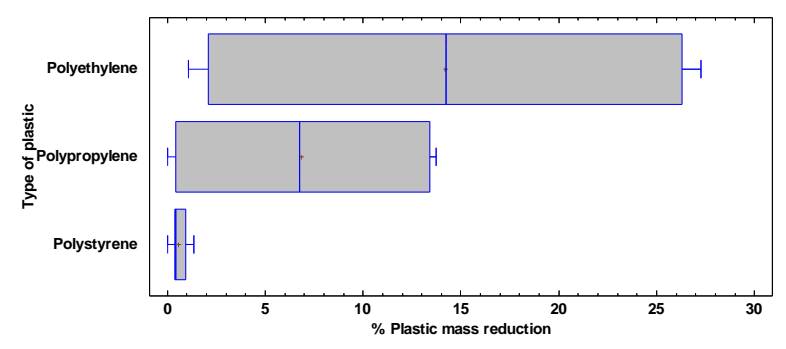

Fig. 10. Box and whiskers for $\%$ reduction in plastic mass according to the type of plastic.

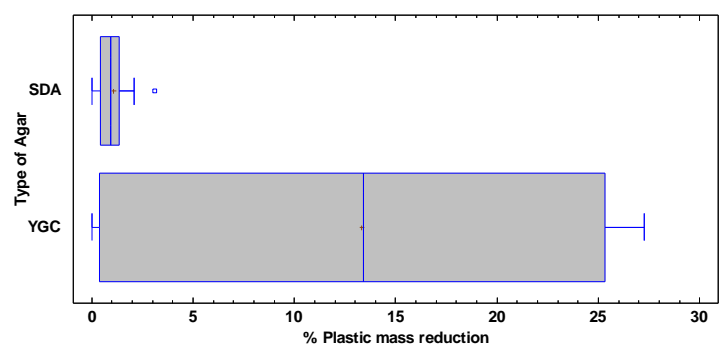

Fig. 11. Box and whiskers for $\%$ of plastic mass reduction according to the type of agar.

\section{DISCUSSION OF RESULTS}

In recent years, the use of plastic has increased to produce bags, bottles, glasses and various types of packaging, which has caused environmental problems that almost immediately become waste after their short-term use. 
Due to this situation, it was sought as an option to study the biodegradation of three types of plastic through the fungus Aspergillus flavus, which showed in the study to have a [16] good degree of plastic transformation.

In this sense, studies such as that of [14], with methodology similar to the one applied in this research, showed percentages of weight loss in a phenolic resin up to $6.3 \%$ considering that the structure of said resin is complex. Research is also reported, such as the one in [17] in which the biodegradation of polyethylene by Bacillus subtilis is studied with the addition of a surfactant that reports a weight loss percentage of $9.26 \%$ after 100 days.

On the other hand, [18] they carried out the biodegradation of low density polyethylene with starch and inocula of bacterial consortia in aqueous medium and found degradation values expressed as weight loss after 150 days, reaching 54.3\%.

In [1] information is presented that shows Aspergillus niger with degradation of polyethylene of $5.8 \%$ after 30 days while Aspergillus japonicius degraded $11.11 \%$ during the same period. The present study with Aspergillus flavus also for polyethylene, shows percentages of degradation of $23.6 \%$ during 100 days, which reaffirms the mentioned reports.

On the other hand, when comparing the results obtained with the two culture media SDA and YGC, it was found that YGC agar had a better behavior in terms of its ability to prevent the formation of bacterial flora by its content of antibiotic chloramphenicol.

This behavior could be evidenced from its isolation in the initial phase until the implementation of the trial.

With the results of the analysis when applying multifactorial ANOVA, it was evidenced that the type of agar used was found to have a higher incidence, and it was also found that YGC agar is more selective for Aspergillus flavus.

Regarding the type of plastic for the two types of agars used, it was found that a better biodegradation is achieved for the polyethylene bag.

Having obtained a $\mathrm{P}$ value of less than 0.05 using the multivariate ANOVA, the alternative hypothesis can be accepted, which states that there are differences between the results obtained with the YGC agar and the SDA agar in all the plastics used in the tests.

In the trial, the following was observed: [19]: "Microorganisms use polyethylene films as the sole carbon source that results in the partial degradation of polyethylene and disposable plastic by colonizing the surface of the high and low density polyethylene films forming a biofilm. "

In some of the trials it was observed under the microscope, that in the case of the SDA culture Aspergillus flavus coexisted with another species of fungus, which was identified as Penicillium sp. In those cases, it could be inferred that the reduction in the percentage of mass of the plastic, could have been the result of the work of both fungi.

\section{CONCLUSION}

The fungus A. flavus with the culture medium of the YGC agar presented better results in the reduction in the weight of plastic compared to another type of agar, in addition it presented less contamination in comparison with other tests.

The culture medium in the SDA Agar presents low biodegradation percentages, representing its low plastic reduction capacity in conjunction with the fungus.

The fungus A. flavus achieved greater biodegradation of polyethylene, compared to other types of plastic such as polypropylene and polystyrene.

The fungus A. flavus proliferated more quickly and with less presence of bacteria and other fungi of the environment in the YGC agar, thus demonstrating its compatibility with this type of medium.

\section{REFERENCES}

[1] L. Yepes, "Degradación de Polietileno de Baja Densidad Utilizando Hongos. Revisión Sistemática de la Literatura”, 2014. [Online]. Available:

https://repository.javeriana.edu.co:8443/bitstream/handle/10554/1618 4/YepesAguirreLauraMaria2014.pdf?sequence $=1$ \&isAllowed=y

[2] S. Khanna, A.K. Srivastava, "A simple structured mathematical model for biopolymer (PHB) production". Biotechnol. Prog. 21, 830-838, 2005, DOI:10.1021/bp0495769.

[3] G. Benitez, "Relleno sanitario bordo poniente: ecópolis". Ciudad de mexico. 2013.

[4] A. Sivan, "New perspectives in plastic biodegradation". Curr Opin Biotechnol 22: 422-426, 2011, DOI:10.1016/j.copbio.2011.01.013.

[5] B. Singh, N. Sharma, "Mechanistic implications in plastic degradation". Polym Degrad Stab 93: 564-581, 2008, DOI:10.1016/j.polymdegradstab.2007.11.008.

[6] SK. Ghosh, S. Pal, S. Ray, "Study of microbes having potentiality for biodegradation of plastics". Environ Sci Pollut Res Int 20: 4339-4355, 2013, DOI:10.1007/s11356-013-1706-X.

[7] A. Bonifaz, "Micología Médica Básica, 5 Ed. Mexico DF: McGrawHill, 2015, pp. 67 - 71: 381 - 396.

[8] D. M, Geiser, J. W. Doner, B. H. Horn and J. W. Taylor, "The phylogenetics of mycotoxin and sclerotium production in Aspergillus flavus and Aspergillus oryzae", Fung Gen and Biol 31: 169-179, 2000, DOI:10.1006/fgbi.2000.1215.

[9] R. Arenas, "Micología médica ilustrada", 5 Ed., Mexico DF: Mc Graw Hill, 2014, pp. $269-279.425$.

[10] J. Yu, T.E. Cleveland, W. C. Nierman, and J. W. Bennett, "Aspergillus flavus genomics: gateway to human and animal health, food safety, and crop resistance to diseases". Revista Iberoamericana de Micología, 22(4), 194-202, 2005, DOI:10.1016/S1130-1406(05)70043-7

[11] K. Willyerd, (). "The Genus Aspergillus and their Mycotoxins in Maize in Mexico: Problems and Perspectives". 2013. [Online]. Available: http://www.scielo.org.mx/scielo.php?script=sci_arttext\&pid=S018533092013000200005.

[12] E. De Diego, P. Bueno, C. Silvestre, M. Cano, O. Berasategi, J. Rea, and S. Salas. "Aspergillus Oryzae y sus parientes", 2016. [Online]. Available

https://aspergillusoryzaeblog.wordpress.com/2016/05/16/aspergillusoryzae-y-sus-parientes/.

[13] T. Debasi, A. M. A. Bekairy, A. M. Alkatheri, Y. A. Al-Ferayan, A. S. Al-Fakhri, and T. Alenazi, "A Successfully Treated Case of Aspergillus Flavus Fungal Keratitis Caused by Stale Bread Corneal Injury", Amer Jour of Medic Case Rep, 4(1), 5-7, 2016, DOI:10.12691/ajmcr-4-1-2

[14] D. Larone, "Medically Important Fungi: A Guide To Identification", ASM Press: Washington, Dc. Pp. 282 - 293, 485p, 2014, DOI: 10.1309/LMW8AT6W4EUIXYBP

[15] B. Rodriguez, "Atlas de identificación micológica", 2016. [Online]. Available: https://atlasdemicologia.wordpress.com/2016/06/22/aspergillusspp/http://aprendeenlinea.udea.edu.co/lms/moodle/mod/page/view.ph $\mathrm{p} ? \mathrm{id}=100812]$ 
[16] R. Cruz, "Guía para el diagnóstico de laboratorio de enfermedad fúngica invasora por hongos filamentosos". Rev Chilena Infectol; 31 (2): 173-179, 2014, DOI: 10.4067/S0716-10182014000200008.

[17] G. I. Ponce Andrade, R. Vázquez Duhalt, R. Rodríguez Vázquez, I. E. Medina Ramírez, J. A. Lozano Álvarez, and J. Jáuregui Rincón, "Evidencia de la biodegradación de resinas fenólicas con hongos ligninolíticos por microscopía electrónica de barrido", Revista Internacional de Contaminación Ambiental. Vol. 28, núm. 2. pág. 159166, 2012. [Online]. Available: https://www.revistascca.unam.mx/rica/index.php/rica/article/view/31 $638 / 29249$

[18] D. Uribe, D. Giraldo, S. Gutiérrez, F. Merino, "Biodegradación de polietileno de baja densidad por acción de un consorcio microbiano aislado de un relleno sanitario", Lima, Perú. Revista peruana de biología 17(1): 133-136, 2010, DOI:10.15381/rpb.v17i1.62

[19] C. Méndez, G. Vergaray, V. Béjar, and K. Cárdenas, "Aislamiento y caracterización de micromicetos biodegradadores de polietileno". Revista Peruana de Biología, 13(3), 203-206, 2006, DOI: $10.15381 /$ rpb.v13i3.2338

[20] P.P. Vimala, L. Mathew, "Biodegradation of Polyethylene using Bacillus subtilis". Procedia Technology 24 232-239, 2016, DOI:10.1016/j.protcy.2016.05.031

[21] K. Veethahavya, B. Rajath, K. S. Veethahavya, B. S. Rajath, S. Noobia, and B. M. Kumar, "Biodegradation of Low Density Polyethylene in Aqueous Media". Procedia Environmental Sciences 35 709-713, 2016, DOI:10.1016/j.proenv.2016.07.072

[22] CH. Vijaya, RR. Mallikarjuna, "Impact of soil composting using municipal solid waste on biodegradation of plastics". Indian journal of biotechnology 235-239, 2008. [Online]. Available: http://nopr.niscair.res.in/bitstream/123456789/1834/1/IJBT\%207\%28 2\%29\%20235-239.pdf

\section{BIOGRAPHICAL REVIEW AUTHORS}

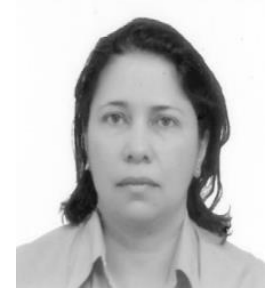

Sandra Santacoloma Londoño. Professor of the Environmental Engineering program of UCEVA since 1995 and to date. It belongs to the Research Group on Natural Resources and Environmental Management Tolúes. She was born in Tuluá, Valle del Cauca; she is a Chemical Engineer of the National University of Colombia in 1994, Specialist in Environmental and Health Engineering of the National University of Colombia in 1998, Master in Engineering of the University of Las Palmas de Gran Canaria, Spain in 2006, Master in Environmental Engineering of CEPES, Mexico in 2013.

Her work experience is as a teacher and she has also developed research and projection activities to the community; orients the research seedbed of the Environmental Engineering program. She directs undergraduate work and develops projects issues such as water analysis and quality, water management, solid waste, land planning and management, heavy metal phytoremediation studies, Biodegradation studies with California red worm and fungal treatment. In text production, she has developed five laboratory manuals and written a book on river water quality.

Its most recent publication, in 2017 she published, the article "Biotransformation of chromium by means of phytoremediation with vetiver (Vetiveria Zizanioides) and later earthworm composting with red californian earthworm (Eisenia foetida)".

She is a consultant to companies and the municipal environmental management (wastewater management and waste sludge treatment) and on these topics is focusing his recent research activity.

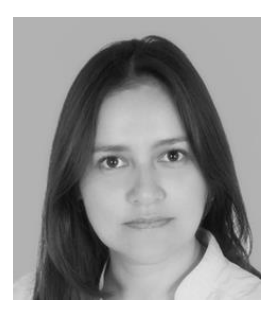

María Eugenia Buitrago González. Professor of the Environmental Engineering program of UCEVA since 1994 and to date. She was born in Buga, Valle del Cauca; she is Graduate in Biology and environmental education of the University of Quindío in 1993, Specialist in Environmental Education of the Santiago de Cali University in 1995, Master in Education with emphasis in Teaching of Natural Sciences of the Universidad del Valle in 2010. She is Associate Professor of the UCEVA in the environmental engineering program, director of a research group on Natural Resources and Environmental management - Tolues.

Her work experience is as a teacher and she has developed research and projection activities to the community and environmental education.

Its most recent publication, in 2017 published, the article "Analysis on sustainable consumption in Colombia as strategy for strengthening its research at the national and local level". She recently developed research on issues related to sustainable consumption and environmental education.

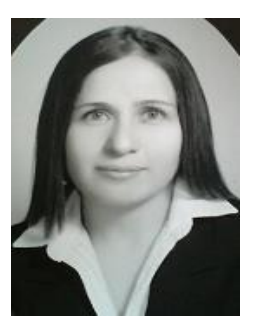

Valentina Valentina Lamus Molina, was born in Tuluá, Valle del Cauca, Colombia in 1982. She received the BS degree in Biology from the Antioquia University, Medellín, Colombia and a MS and PhD degrees in Agricultural Sciences and Natural Resources from the Autonomous University of the State of Mexico, Toluca, Mexico in 2011 and 2015. From 2016 to 2018 she was a Research with Inciva, Cali. Since 2018, she currently works as a proffesor of Botany, Phytopathology and Plant Breeding in the Central Unit of Valle del Cauca in the Agricultural Engineering program and belongs to the Proagro and Tolues research groups.

Her research interest include taxonomic study of phytopathogenic and mycorrhizal fungi and their interaction with plants of agricultural and forestry importance by morphological and molecular techniques. Dr. Lamus was awarded with a scholarship from Conacyt, México during her master and PhD study programs in 2009 and 2015. She is author of three articles in Mycologia, Mycoscience and Annals of Biology in 2012 and 2015. She is member of the Association of Biologists from the University of Antioquia, since 2015.

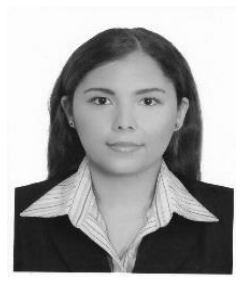

Staphani Asprilla Asprilla, was born in Buenaventura, Valle del Cauca. She is Environmental Engineer graduated from the U. Central del Valle del Cauca. He participated in the research group Tolues. 


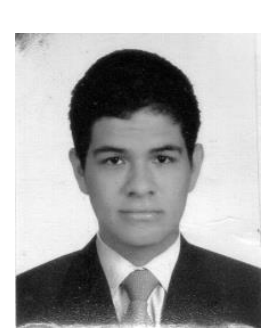

Juan Esteban Ruíz Terán, was born in Buga, Valle del Cauca. He is Environmental engineering student. Member of the research group Tolues. Research Monitor. He has received recognition for his academic performance.

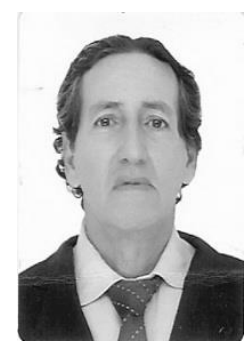

Luis Carlos Villegas Méndez, was born in Tuluá, Valle del Cauca, Colombia in 1954. He received the BS degree in Agronomy Engineering from the University of Caldas, Manizales in 1978 and the MS in Biological and Naturist Studies from the University of León, Spain in 2012.

He worked as Sectional Boss in National Cocoa Federation, Chocó-Risaralda, Colombia. From 1994 to 1997 he was an Assesor in the International Center of Organic Agriculture, Risaralda, Colombia. Since 1997 he is Associate Professor of the Central Unit of Valle del Cauca, UCEVA, in the Environmental Engineering program.

$\mathrm{He}$ is author of the books titled "Environmental Education Strategy in Sustainable Consumption Habits" (American School of Leadership, 2013) and "Fruitculture. Medicinal findings in 80 consumption fruits in Colombia" (Grafiartes Ltda., 2017). Ms Villegas-Méndez is member of the Research Group in Natural Resources and Environmental Management, Tolues and the Italo-American ethnomedicine Society, University of Salerno, Italy. He is Director of the research seedbed in Habits of Sustainable Consumption since 2013. 